\title{
First report of a permanent open form of a naphthopyran
}

\author{
Cristina I. Martins ${ }^{\mathrm{a}}$, Paulo J. Coelho*a ${ }^{*}$ Luis M. Carvalho ${ }^{\mathrm{a}}$, Ana M.F. Oliveira-Campos ${ }^{\mathrm{b}}$ \\ ${ }^{a}$ Dept. Química, Universidade de Trás-os-Montes e Alto Douro, 5000 Vila Real, Portugal \\ ${ }^{\mathrm{b}}$ Centro de Química, IBQF, Universidade do Minho, 4710 Braga, Portugal
}

\begin{abstract}
The synthesis of a permanent open form of a naphthopyran is described for the first time. The open form of the 10-hydroxy-2H-naphtho[1,2-b]pyran, obtained by reaction of 1,8-dihydroxynaphthalene with 1,1-diphenylprop-2-yn-1-ol under acid catalysis, is stable due to the establishment of an intramolecular hydrogen bond.
\end{abstract}

Key Words: photochromism, naphthopyrans, hydrogen-bond, phenols

\section{Introduction}

Organic photochromic materials have been extensively studied because of their use in plastic sunglass lenses ${ }^{1}$ and also due to other potential applications such as in optical memories and optical switches. ${ }^{2}$ Naphthopyran solutions are essentially colourless or weakly coloured and upon near UV irradiation acquire progressively an intense yellow, orange, red, purple or blue colouration depending of the type of substitution and annellation. When the UV light is removed the solution becomes colourless (Scheme 1). The absorption of light promotes the cleavage of the C-O bond of the naphthopyran (usually refereed to as the "closed form”), leading to a set of isomers with the pyran ring open (the "open form”). The open form returns to the naphthopyran form by a thermally or photochemically induced ring closure reaction. The observation of a distinct absorption spectrum is due to the extensively conjugated $\pi$ system present in the open form. ${ }^{3}$

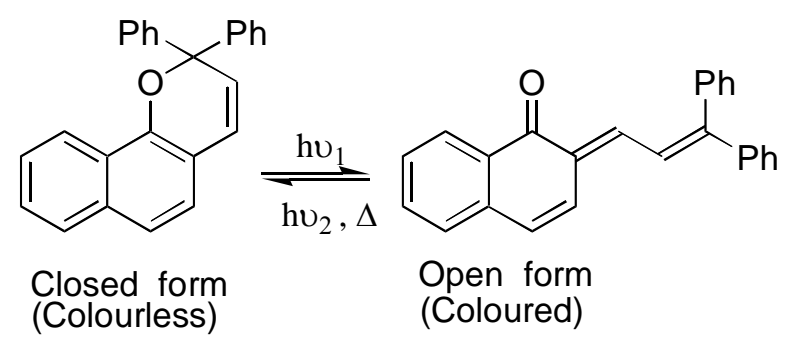

Scheme 1

The open forms are usually short-lived states and the time scale is very dependent on the presence of substituents. Their structures have been studied by low-temperature NMR experiments on long- 
lived forms under UV irradiation ${ }^{4,5}$ or deduced from analysis of the products obtained by reduction with $\mathrm{LiAlH}_{4}{ }^{6}{ }^{\mathrm{NMR}}$ studies of the open form of 3,3-diphenyl-3H-naphtho[2,1-b]pyran support a structure best represented by a quinoidal species instead of its possible zwitterionic form. ${ }^{7}$

To understand the photochromic mechanism it is essential to be aware of the structure of the open form. Open forms have only been isolated, in the past, on the spiropyran ${ }^{8}$ or spirooxazine ${ }^{9}$ series, $^{2}$ the increase on the electronic conjugation being used as a mean of stabilisation. ${ }^{9}$ Some examples of the existence of a thermal equilibrium between spirooxazines and their open forms have also been reported but the equilibrium lies towards the closed form. ${ }^{10}$

The introduction of an $\mathrm{OH}$ group in position 10 of a naphthopyran which would allow for the formation of an intramolecular hydrogen bond would, in principle, induce stabilisation of the open form.

Naphthopyrans are usually prepared, in reasonable yield, through reaction of naphthols with 1,1diphenylprop-2-yn-1-ol in the presence of a catalytic amount of pyridinium $p$-toluenesulphonate (PPTS). In order to synthesise the desired compound, 1,8-dihydroxynaphthalene 1 was needed. This phenol was prepared in low yield by fusing a mixture of $\mathrm{KOH}, \mathrm{NaOH}$ and naphthosultone for 5 hours. ${ }^{11}$ After acid hydrolysis 1,8-dihydroxynaphthalene $\mathbf{1}$ was isolated in 24\% yield. When a toluene solution of 1,8-dihydroxynaphthalene 1, 1,1-diphenylprop-2-yn-1-ol and PPTS was heated for $2 \mathrm{~h}$, the red dye 2 was obtained, which proved to be a stable open form of the 10-hydroxy- $2 \mathrm{H}$ naphtho[1,2-b]pyran (Scheme 2). ${ }^{12}$<smiles>Oc1cccc2cccc(O)c12</smiles>

1

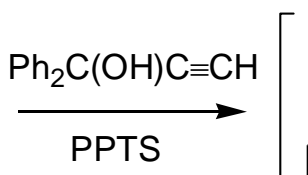

$65 \%$<smiles>Oc1cccc2ccc3c(c12)OC(c1ccccc1)(c1ccccc1)C=C3</smiles>

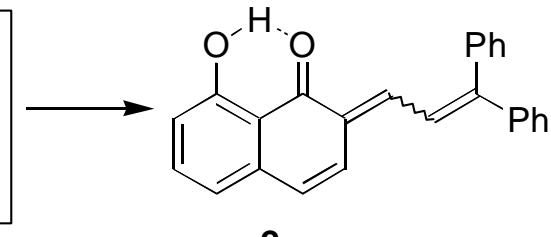

2

Scheme 2

The presence of an intramolecular chelating $\mathrm{H}$-bond was established by ${ }^{1} \mathrm{H}$ NMR analysis of compound 2 which showed a characteristic singlet at $13.24 \mathrm{ppm}$. On the other hand ${ }^{13} \mathrm{C}$ NMR of this compound showed the presence of a carbonyl at $190.05 \mathrm{ppm}$. The predominance of the open form over the "closed" naphthopyran is $\mathrm{pH}$ dependent. Thus, in acidic methanol solution the open form is predominant, but in basic methanol solution the equilibrium is completely shifted towards the “closed” naphthopyran form which does not absorb in the visible region (Fig. 1).

This was also confirmed through ${ }^{1} \mathrm{H}$ NMR analysis of the red dye 2 in MeOD adding DCl and NaOD. ${ }^{13}$ Under acidic conditions only one compound, corresponding to the open form, is observed. 
Adding NaOD (excess) the NMR spectrum changes completely and can be attributed to the closed form of a naphthopyran (Scheme 3).

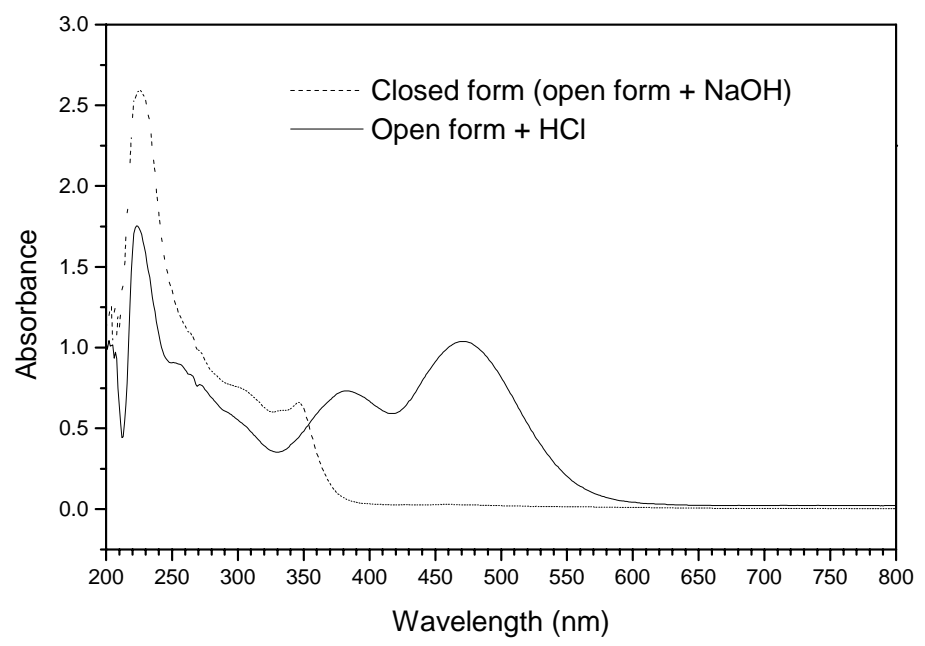

Figure 1<smiles>CC[n+]1ccc2c(=O)/c(=C/C=C(c3ccccc3)c3ccccc3)ccc3cccc1c32</smiles>

Scheme 3

This conversion is reversible but it was observed that the closed naphthopyran form underwent complete degradation after being maintained for a few hours, under basic conditions.

In order to prove that the hydrogen bond is essential for the stabilisation of the open form, the synthesis of 10-acetoxy-2H-naphtho[1,2-b]pyran 4 where this intramolecular interaction is avoided, was carried out. Treatment of an aqueous solution of 1,8-dihydroxynaphtalene 1 with acetic anhydride in the presence of $\mathrm{K}_{2} \mathrm{CO}_{3}$ gave the monoacetate $3^{14}$ which was then converted to naphthopyran 4 using the usual procedure (Scheme 4). This naphthopyran is stable in solution at room temperature and exhibits photochromic behaviour.<smiles>Oc1cccc2cccc(O)c12</smiles>

1
$\underset{\mathrm{Ac}_{2} \mathrm{O}}{\stackrel{\mathrm{K}_{2} \mathrm{CO}_{3}(\mathrm{aq})}{\longrightarrow}}$

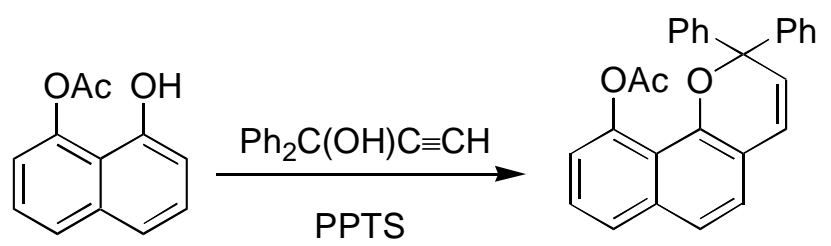

3 
Although only one compound was observed by NMR, there are two possible stereoisomers of the open form 2, the TT isomer (2a) and the CT isomer (2b). The CT isomer is believed to be more stable involving a supplementary hydrogen-bond in a six ringed system and steric interactions being less important. ${ }^{5}$ We have determined for the red dye 2 a molar absorption coefficient of $1.7 \times 10^{4}$ $\mathrm{dm}^{3} \mathrm{~mol}^{-1} \mathrm{~cm}^{-1}\left(\lambda_{\max }=471 \mathrm{~nm}\right)$ in acetone, which is comparable to the ones determined for two spirooxazine opened forms $\left(\varepsilon=4.8\right.$ and $\left.4.9 \times 10^{4} \mathrm{dm}^{3} \mathrm{~mol}^{-1} \mathrm{~cm}^{-1}\right){ }^{9} \quad$ NMR studies involving NOESY and COSY investigations can bring more structural information about the structure of the open form.

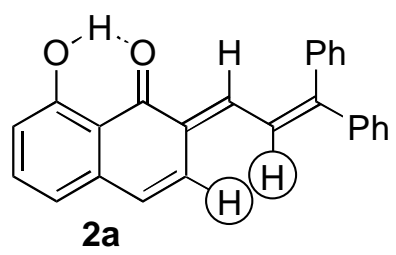

$2 a$<smiles>O=c1ccc2cccc(O)c2cc1</smiles>

\section{Acknowledgments}

To FCT for financial support through project Praxis XXI/P/QUI/10021/1998. To Elisa Pinto for NMR spectra monitoring.

\section{References}

1. Van Gemert B. Organic Photochromic and Thermochromic Compounds, Crano, J. C.; Guglielmetti, R. J. , Eds.; Plenum Publishing Corporation, New York, 1999; Vol. 1, Chapter 3.

2. Ichimura, K. Photochromism: Molecules and Systems, Dürr, H.; Bouas-Laurent, H., Eds. ; Elsevier, Amsterdam, 1990; Chapter 26.

3. Laarhoven W. H. Photochromism: Molecules and Systems, Dürr, H.; Bouas-Laurent , H. , Eds.; Elsevier, Amsterdam, 1990. Chapter 7.

4. Delbaere, S.; Bochu, C.; Azaroual, N.; Buntinx, G.; Vermeersch, G.; J. Chem. Soc. Perkin Trans. 2, 1997, 1499-1501.

5. Delbaere, S.; Luccioni-Houze, B.; Bochu, C.; Teral, Y.; Campredon, M.; Vermeersch, G.; J. Chem. Soc. Perkin Trans. 2, 1998, 1153-1157.

6. Kolc, J.; Becker, R.S. J. Phys. Chem., 1967, 71, 4045-4047.

7. Crano, J.C.; Flood, T.; Knowles, D.; Kumar A.; Van Gemert, B. Pure \& Appl. Chem. 1996, 68, 1395-1398.

8. Samat, A. M.; Guglielmetti, R. J.; G. J. Martin, Org. Magn. Reson, 1976, 8, 62. 
9. Laréginie, P.; Lokshin, V.; Samat, A.; Guglielmetti, R.; Pèpe, G. J. Chem. Soc. Perkin Trans. 2, 1995, 107.

10. Pozzo, J. L.; Samat, A.; Guglielmetti, R.; De Keukeleire, D. J. Chem. Soc. Perkin Trans. 2, 1993, 1327.

11. Bender, M. L.; Lawlor, J. M. J. Am. Chem. Soc., 1963, 85, 3010.

12. Procedure for the synthesis of 2: To a mixture of 1,8-dihydroxynaphthalene 1 (201 mg, 1.26 mmol), 1,1-diphenylprop-2-yn-1-ol (563 mg, $2.70 \mathrm{mmol}$ ) and PPTS (20 mg) $60 \mathrm{ml}$ of dry toluene were added. The suspension was refluxed for 2 hours under an argon atmosphere. The toluene was evaporated under reduced pressure and the red oil which was obtained, purified by silica gel column chromatography $\left(\mathrm{CH}_{2} \mathrm{Cl}_{2}\right.$ /hexane 20-60\%). Recrystallization from methanol gave a crystalline material: 285 mg, 65 \%; Mp.146-148 ${ }^{\circ} \mathrm{C}$; IR: 3409, 3029, 2870, 1724, 1625, 1550, 1440, 1241; ${ }^{1} \mathrm{H}$ NMR (300 MHz, $\left.\mathrm{CDCl}_{3}\right) \delta 13.24(s, 1 \mathrm{H}, \mathrm{OH}), 8.10$ (d, 1H, J=7.7 Hz), $7.78(d, 1 \mathrm{H}, \mathrm{J}=8.0 \mathrm{~Hz}), 7.53$ (d, 1H, J=9.0 Hz), $7.51(m, 2 \mathrm{H}), 7.42-7.31(m, 9 \mathrm{H}), 7.11(d, 1 \mathrm{H}, \mathrm{J}=7.5 \mathrm{~Hz}), 6.93(d, 1 \mathrm{H}, \mathrm{J}=7.8 \mathrm{~Hz})$, 6.57 (d, 1H, J=8.0 Hz), ${ }^{13} \mathrm{C}$ NMR: 190.05, 162.52, 153.35, 141.51, 138.54, 137.14, 136.64, 134.07, 131.07, 129.39, 129.02, 128.59, 128.46, 126.33, 122.35, 116.25, 112.82; MS-EI m/z 167 (12), 191 (20), 231 (12), 237 (17), $350\left(\mathrm{M}^{+}, 100\right)$. Exact mass for $\mathrm{C}_{25} \mathrm{H}_{18} \mathrm{O}_{2}$ : 350.130680; Found 350.130595. 13. ${ }^{1} \mathrm{H}$ NMR (300 MHz) spectrum of the red dye 2 in $\mathrm{CH}_{3} \mathrm{OD}: \delta 8.41(\mathrm{~d}, \mathrm{~J}=10 \mathrm{~Hz}, 1 \mathrm{H}), 7.81(\mathrm{~d}$, $\mathrm{J}=8 \mathrm{~Hz}, 1 \mathrm{H}), 7.76$ (d, J= $8 \mathrm{~Hz}, 1 \mathrm{H}), 7.60-7.30$ (m, 11H), 7.30 (d, J= $8 \mathrm{~Hz}, 1 \mathrm{H}), 6.90$ (d, J= 7.5 Hz, 1 $\mathrm{H}), 6.58$ (d, J= $10 \mathrm{~Hz}, 1 \mathrm{H}$ ); in $\mathrm{CH}_{3} \mathrm{OD}+\mathrm{NaOD}: \delta 7.40$ (m, 2H), 7.30-7.16 (m, $\left.10 \mathrm{H}\right), 7.04$ (t, J= 8 Hz, 1H), 6.86 (d, J= 8 Hz, 1H), 6.49 (d, J= $8 \mathrm{~Hz}, 1 \mathrm{H}), 6.41$ (d, J= $8 \mathrm{~Hz}, 1 \mathrm{H}), 6.39$ (d, J= $8 \mathrm{~Hz}, 1 \mathrm{H})$. 14. Hilbert, F.; Spiers, K. J. Chem. Soc. Perkin Trans 2, 1988, 571. 